\section{Trinta anos após um filho na adolescência}

\author{
Humberto Corrêa*
}

\begin{abstract}
FURSTENBERG, Frank F. Destinies of the disadvantaged: the politics of teenage childbearing. New York: Russell Sage Foundation, 2007. $203 p$.
\end{abstract}

Lançado em novembro de 2007, mas ainda sem tradução para o português, Destinies of disadvantaged é a resolução de uma pesquisa que, metodologicamente, remete a uma aspiração de demógrafos e cientistas sociais afeitos aos temas fecundidade, família, nupcialidade e gerações: a oportunidade de poder acompanhar uma coorte por décadas.

Precedido de outros dois volumes, ambos derivados do projeto The Baltimore Study, o livro sintetiza uma pesquisa iniciada em meados dos anos 1960, ocasião em que o autor começou o acompanhamento de uma coorte de aproximadamente 300 mães adolescentes. Entrevistadas pela primeira vez ainda durante a gravidez, quase todas as jovens foram ouvidas em outras seis ocasiões ao longo dos 30 anos subsequentes ao primeiro contato.

Trata-se de uma visão longitudinal, com uma profusão de informações raramente observada na produção acadêmica: família, trabalho, educação, domicílio, vida financeira e existência de morbidades compõem apenas um pequeno conjunto de dimensões observadas pelo autor.

O livro responde como essas mães enfrentaram os obstáculos da vida pós- fecundidade e em que medida o evento afetou suas famílias, seus filhos e suas próprias biografias.

Ao longo dos 30 anos de pesquisa e dos 40 que separam a publicação das primeiras entrevistas -, a consideração da temática sofreu inúmeras mudanças e novas perspectivas de análises foram sucessivamente introduzidas. O próprio autor foi influenciado pelas ideias dominantes que pautaram a conjuntura da agenda de pesquisa. Aqueles que conhecem sua produção identificam a revisão de conceitos, a ponderação de opiniões e a incessante busca de comprovação das novas argumentações que se apresentaram. Enfim, a construção de uma trajetória cingida por avanços e retrocessos que outorgam méritos adicionais ao seu trabalho. Como resultado, em nossos dias, poucos pesquisadores possuem a expertise de Furstenberg para analisar a questão.

Originalmente interessado em políticas públicas no início do estudo, Furstenberg rastreou a conformação do "problema" da gravidez na adolescência do que qualifica de "quase invisibilidade social" até o status de maior "problema social nos EUA nos anos Reagan".

A visão crítica do texto denuncia como a apropriação política da questão e a sua influência nas pesquisas produzidas no âmbito das ciências sociais exageraram as consequências da fecundidade na adolescência, tanto para as protagonistas como para suas famílias e filhos. Portanto, seu texto igualmente discute como o poder das forças exógenas acomete a produção acadêmica que, no tema em questão, muitas vezes se deixou pautar mais por interesses políticos do que na busca pelo avanço do conhecimento.

Assim, a fragmentação do tema serviu para municiar demandas tão diversas como o teor de programas de planejamento familiar, a legalização do aborto, os programas

\footnotetext{
* Mestre em Estudos Populacionais e Pesquisas Sociais pela Escola Nacional de Ciências Estatísticas (Ence/IBGE) e doutorando em Demografia na Universidade Estadual de Campinas (IFCH/Unicamp).
} 
de bem-estar social e a defesa do casamento, que, de qualquer forma, estariam em foco não obstante recorressem a outros argumentos para cosubstanciá-los.

Para o período analisado, o autor abordou as políticas - algumas com efeitos adversos para as mães, seus filhos e suas famílias - formuladas para combater a fecundidade na adolescência nos EUA, concluindo que seus efeitos sociais e econômicos de longo prazo foram módicos - senão nulos. Além disso, Furstenberg comprova que as consequências do evento na vida das jovens distaram, sobremaneira, dos argumentos que povoam o senso comum, o qual, via de regra, remete a ideias de vidas comprometidas em função de uma gravidez levada a termo durante a adolescência. Em verdade, evidencia o autor, a fecundidade foi protagonizada por jovens que já estavam inseridas na pobreza e sobrecarregadas com inúmeros déficits sociais.

Furstenberg sugere, então, que a postergação de um filho por alguns anos provavelmente as livrariam de figurar nas estatísticas sobre a fecundidade na adolescência, mas teriam efeito pífio em suas trajetórias.

Em suas próprias mensurações e em análise de uma vasta bibliografia - que, per se, justificam a leitura da obra -, o autor conclui que jovens muito pobres, com ou sem filhos, em geral alcançam resultados próximos em termos educacionais e econômicos. E se as estatísticas, por vezes, demonstram que as jovens sem filhos se saem melhor em alguns indicadores, em geral, argumenta Furstenberg, não computaram adequadamente as circunstâncias anteriores à fecundidade e, portanto, tendem a refletir não mais do que um efeito de seletividade.

O pesquisador postula a existência de inúmeras boas razões para que uma sociedade se esforce em reduzir a fecundidade na adolescência. Entretanto, baseado em evidências, ele conclui que há superestimação do potencial de redução da pobreza mediante a diminuição das taxas de fecundidade entre as adolescentes.

De sua argumentação, inferimos que, em vez de a gravidez na adolescência ser a origem da pobreza dessas jovens, cometerse-ia menor erro se afirmássemos tratar-se da sua consequência. Assim, a fecundidade durante os anos da adolescência não traduziu um grande impacto na vida da maioria das jovens pesquisadas. Em geral, elas já eram pobres e essa foi a "desvantagem" que antecedeu sua fecundidade e, por conseguinte, constituiu a maior responsável - mas não a única - por seus "destinos".

Recebido para publicação em 07/12/2009 Aceito para publicação em 18/02/2010 